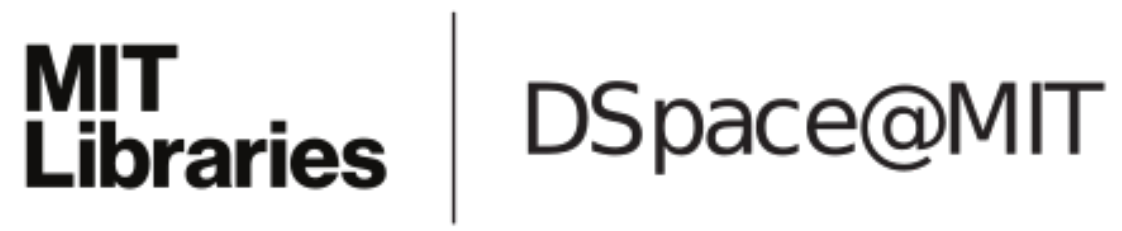

\author{
MIT Open Access Articles
}

The Genders of Waves

The MIT Faculty has made this article openly available. Please share how this access benefits you. Your story matters.

Citation: Helmreich, Stefan. “The Genders of Waves.” WSQ: Women's Studies Quarterly, vol. 45, no. 1-2, 2017, pp. 29-51.

As Published: http://dx.doi.org/10.1353/WSQ.2017.0015

Publisher: Johns Hopkins University Press

Persistent URL: http://hdl.handle.net/1721.1/114218

Version: Author's final manuscript: final author's manuscript post peer review, without publisher's formatting or copy editing

Terms of use: Creative Commons Attribution-Noncommercial-Share Alike 


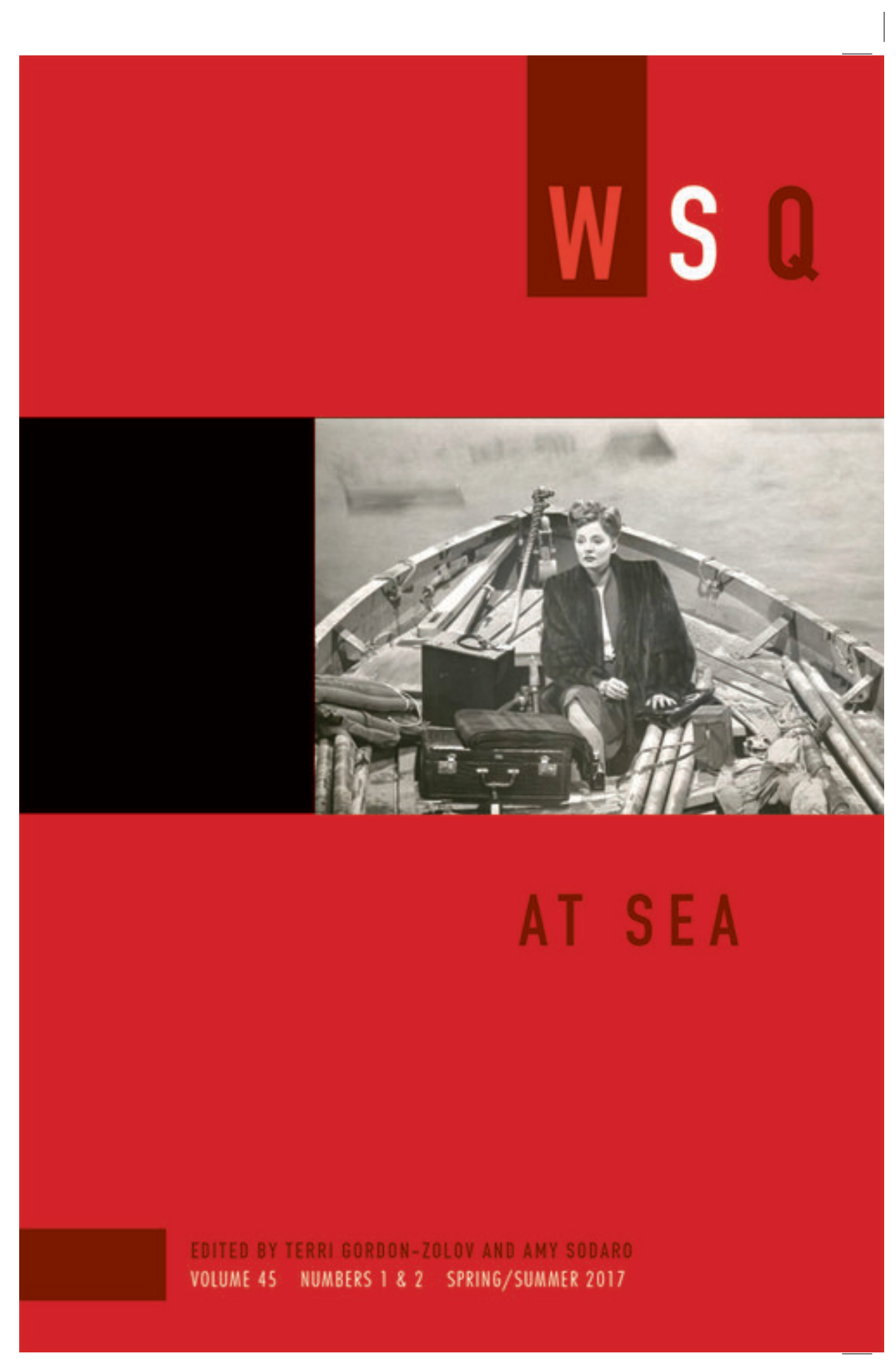

\section{The Genders of Waves}

Stefan Helmreich

Abstract: Seeing the sea as a feminine force and flux has a long history in the crosscurrents of Judeo-Christian thought, Enlightenment philosophy, and natural scientific epistemology. This essay examines how ocean waves and natural scientific epistemology. This essay examines how ocean waves
have been similarly gendered female, and also flips that inquiry, asking how women's collective agency has been figured through wave metaphors, notably in discussions of U.S. feminism. I examine how such depictions of waves have called upon and naturalized a gendered symbolism but may these days-particularly in the age of attention to the "nonhuman"-be coming undone, rendering gender newly "at sea."

Seeing the sea as a feminine force and flux has a storied history in the crosscurrents of Judeo-Christian thought, Enlightenment philosophy, and natural scientific epistemology. The ocean has been motherly amnion, fluid matrix, seductive siren, and unruly tide, with these castings opposing such putatively heteromasculine principles as monogenetic procreative power, ordering rationality, self-securing independence, and dominion over the biophysical world (see Bachelard 1983; Irigaray 1985; Theweleit 1987; Grosz 1994). At other moments, the ocean has been masculine, the embodiment of Poseidon or Yahweh, or of the virile power of storms and vigorous hydrotherapy. This essay examines how ocean waves-icons of rhythmic and predictable motion as well as of chaos and destructionhave been similarly gendered, and asks particularly after descriptions of waves as women. It also flips that inquiry, questioning not only the gyno(and anthro- and zoo-) morphism of wave symbolism but also how the wave metaphor has configured narrations of women's social history, espe-

WSQ: Women's Studies Quarterly 45: 1 \& 2 (Spring/Summer 2017) @ 2017 by Stefan Helmreich. All rights reserved. 
cially in the case of waves of feminism in the United States. I suggest that rhetorical relays between "waves" and "women" have animated and naturalized a shifting store of gendered symbolisms.

I revisit the gendering of waves at a moment when the humanities have turned toward the material world in hopes of making sense of the domain of the "posthuman," "multispecies," "nonhuman," and "inhuman" (Barad 2008; Wolfe 2009; Braidotti 2013; Kirksey 2014; Grusin 2015; Cohen 2015). With the arrival of "new materialisms" (Coole and Frost 2010) tuned to "vibrant matter" (Bennett 2010), the ocean has become a site of "wet ontologies," a zone of "three-dimensional and turbulent materiality" (Steinberg and Peters 2015, 247). Traces and fragments of the "human" still haunt such ahumanisms, particularly as geologists come to call our time the Anthropocene (Crutzen and Stoermer 2000), tagging the present epoch as indelibly marked by the environmental damage wrought by human enterprise. Timothy Morton (2013) calls Anthropocenic objects such as the globe and climate "hyperobjects"-phenomena that exist on massive scales; he describes such objects as viscous, nonlocal, temporally undulating, and phasing.

The scales and registers at which hyperobjects operate-and ocean waves are nothing if not viscous, nonlocal, temporally undulating, and phasing - would seem far from arenas in which gender is relevant. But, as Judith Butler observed in Bodies that Matter (1993), the very notion of "matter," at least in languages tangled up with Latin, has been densely figured as female, as matrix, mater, and more-an inheritance difficult to fully escape. The swell of today's new materialisms must not forget the durability of gender as a semiotic force.

That said, gendered castings of the sea and waves have always been unstable and may be, increasingly, coming undone (on "undoing gender," see Butler 2004). Gender is a concept created "to contest the naturalization of sexual difference" (Haraway 1991, 131) and employed, in concer with race, class, and other analytics, to decode how inequalities manifest across human bodies and selves. But it may also be adapted to discern and upturn the assignation of sex, sexuality, and other genres of difference to nonhuman entities, including the sea. The present essay, allying with "Anthropocene feminism" (Alaimo 2016) and queer critical-race accounts of the "animacies" of metals and toxins (Chen 2012), follows waves as material-formal entities whose descriptions have been shaped and reshaped by rhetorics of gender. In this essay's two sections-one on ocean waves (mostly) gendered as women, and the other on women's collective agency described using wave metaphors-I wind through Judeo-Christian imagery as well as Euro-American mythology, and also examine turns in U.S. women's history. Theoretical attention toward the nonhuman or aggregate human does not on its own escape gender symbolisms - though, in putting such analytics into turbulence, it may render them newly unsteady. ${ }^{1}$ Read this way, today's gender-bent and -rent waves might be signs of how the analytic of gender may itself be viscous, undulating, and phasing: at sea.

\section{Waves as Women .... and Sometimes Men and Animals}

Essayist Jonathan Raban writes, "Of all natural symbols, the breaking wave is the most laden with suggestive meanings. For several thousand years, the waves have been talking power and sex and death to us" $(2010,159)$. It may therefore not be a surprise that waves-at least in the West, the parochial focus of this section-have spoken in symbolisms of gender. In Male Fantasies, Klaus Theweleit offers examples of how invocations of watery flow have been filtered through masculinist anxieties, forms that have made waves into a curl of subaltern feminine imagery:

A river without end, enormous and wide, flows through the world's literatures. Over and over again: the women-in-the-water; woman as water, as a stormy, cavorting, cooling ocean, a raging stream, a waterfall, as a limitless body of water that ships pass through ... woman as the enticing (or perilous) deep; as a cup of bubbling body fluids; the vagin as wave, as foam ... love as the foam from the collision of two waves, as a sea voyage. $(1987,283)$

Tara Rodgers, in her dazzling work on the gendering of sound waves (2016), argues that waveform inscriptions, which purify waves into curvilinear forms, tame what Elizabeth Grosz names as "a formlessness that engulfs all form, a disorder that threatens all order" $(1994,203)$. Drawing on Luce Irigaray, who observes that "historically the properties of fluids have been abandoned to the feminine" $(1985,116)$, Rodgers suggests that natural philosophy ideologies in the West have had "waves [as] ... both form-giving... and perpetually in excess of formal representation" (2016, 202-203). ${ }^{2}$

Where to begin an historical investigation of the gendering of waves? Perhaps, following feminist theologian Catherine Keller, with the Bible. In 
The Face of the Deep: A Theology of Becoming (2003), Keller argues that patristic Christian readings of Genesis have interpreted the void introduced in verse 1:2, "And the earth was without form and void; and darkness was upon the face of the deep," as either a nothingness from which God created the cosmos ex nihilo or as a chaotic, fluid, and maternal principle tamed by a monogenetic masculine God. The "deep," tehom in Hebrew, Keller observes, derives from Tiamat, the Babylonian goddess of the ocean, a motherly principle subsumed into the syncretic Biblical creation tale. "What happened," asks Keller, "to the chaos of Genesis 1:2? ...Was it murdered? Was it a 'she'?" Keller writes, "The void evinces fullness, its water's viscosity ... the second verse sends a mysterious tremor through the whole narrative of creation" $(2003,9)$. For early Christian writers, the "tehomic alterity which has been relegated to the outer darkness threatens to flow back monstrously: the flux, repressed, returns as the flood" (10; emphasis in original). Keller attends to the wave as a figure of disavowed origin: "While Augustine struggles against the mortal materiality of his maternal bond, the oceanic imaginary deluges the text: 'I fought against the wave of sorrow and for a while it receded but then it swept upon me again with full force"” (72).

Noah's flood survives as the excess of Creation, with waves the echoing substance of that inundation, a flood that God keeps at bay. In Job, Yahweh declares His power over the seas: "Here you may come, but no farther, here your proud waves break” (130). Fourth-century bishop Basil of Caesarea wrote that at the moment when the sea meets the land, it "withdraws out of respect, bowing its waves, as if to worship the Lord who has appointed its limits" (quoted in Corbin 1995, 26-27). Waves are at one moment defiant agents of disorder and at another pious believers, their agency oscillating.

Waves gather an explicitly gendered agency in another tradition of thinking through the supernatural. In Old Norse mythology, the nine daughters of Ægir, the god of the sea, and Rán, the goddess of the drowned are ocean waves, and each manifests a different wavy form (fig. 1). In the Prose Edda, by Icelandic poet Snorri Sturluson and compiled around 1200, these daughters are named: Himinglæva, "that through which one can see the heaven"; Dúfa, "the pitching one"; Blódughadda, "bloody hair"; $\mathrm{He}$ fring, "riser"; Udr, "frothing wave"; Hrönn, "welling wave”; Bylgja, "billow"; Bára, "foam fleck"; and Kolga, "the cool one."

In Norse stories, these "wave maidens" afflict seafarers by embodying their father's force and their mother's mercilessness. Judy Quinn writes

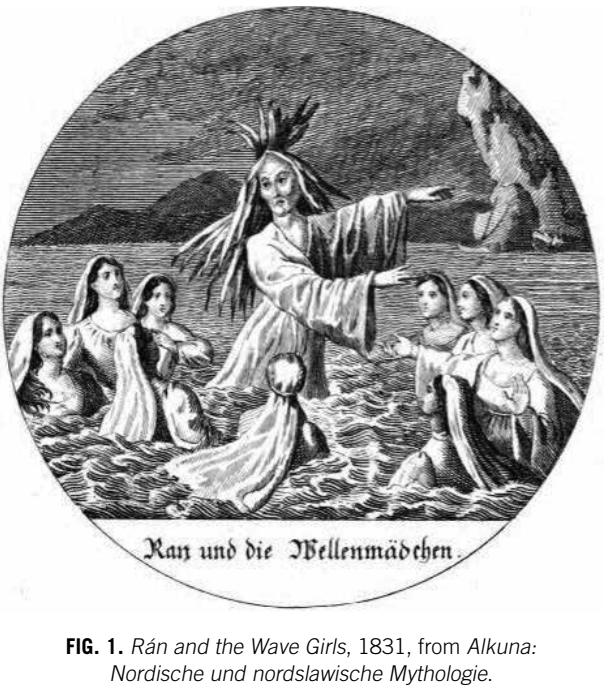

that in Edda stanzas in which "names are deployed, the personified wave is ascribed agency, and often rather willful agency... female personifications of the sea [are] imagined as nubile, alluring, self-willed, determined, and destructive" (2014, 90-94). Quinn gives a sample in which wave maidens vex male sailors:

Who are those brides who go along in the surf-skerries and have thei journey along the fjord? They have a hard bed, the white-hooded ones, and they play little in the calm.... Who are those women who go around together? Seldom are they gentle with the band of men, and they are awakened in the wind. . They have pale hair, the white-hooded ones, and those women do not have husbands. $(2014,94)$

These are wild, scary women. To Barbara Ehrenreich in her foreword to Theweleit's Male Fantasies, such manifestations give body to a masculinist dread of "a nameless [feminine] force that seeks to engulf-described over and over as a 'flood,' a 'tide,' a threat that comes in 'waves"' $(1987, \mathrm{xv})$.

In a later tale, the wave women are mothers of Heimdallr, a Norse god who keeps watch for Ragnarök, the world-ending battle among the gods 
in Eddic eschatology (fig. 2). Some scholars offer that Heimdallr was the child of Odin and one maiden, while others suggest the wave maidens collectively generated Heimdallr (Lindow 2001). W. G. Collingwood's 1908 woodcut, Heimdal and His Nine Mothers, envisions the maidens as embodied water. The wave maidens move from stern temptresses to maternal, protective figures. Their whiteness seems to be echoed in an 1885 poem by Henry Wadsworth Longfellow, in which he poses waves as delicate carriers of mournful news about the evanescence of life:

The little waves, with their soft, white hands

Efface the footprints in the sands.

And the tide rises, the tide falls

$(1885,289)$

Waves here offer a durable deliquescence-one supported by a whiteness that may also animate a racialized femininity. Compare this to Hortense Spillers on one oceanic trajectory for the making of blackness, in which "African persons in the 'Middle Passage' were literally suspended in the 'oceanic," captured in an "undifferentiated identity" that made of them "ungendered flesh" $(1987,72,68)$. For audiences at the turn of the twentieth century, the whiteness of wave women may have gone hand in glove with their anthropomorphization.

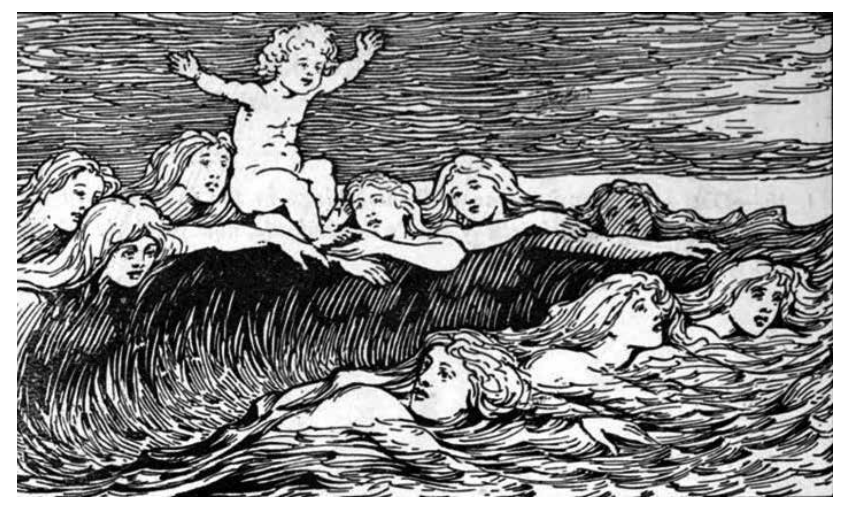

FIG. 2. W. G. Collingwood, Heimdal and His Nine Mothers. Woodcut, 1908.
Waves, like genders, are malleable things. The defiance of waves gathers a secular cast in Friedrich Nietzsche's The Gay Science ([1882] 1974) that book in which he states "God is dead"-in which they become emissaries of unrepentant modernity: "How greedily this wave approaches, as if it were after something! How it crawls with terrifying haste into the inmost nooks of this labyrinthine cliff! . . But already another wave is approaching, still more greedily and savagely than the first, and its soul, too, seems to be full of secrets and the lust to dig up treasures. Thus live waves-thus live we who will" (247). Eugene Victor Wolfenstein (2000) argues that these waves embody a Nietzschian valorization of a masculine will to power. Nietzsche's waves have an affinity, too, with Greek mythological renderings of waves as horses. As Tamra Andrews writes, "white crests resembled the horses' billowing manes. Breakers, or particularly strong waves, were sometimes referred to as wild bulls" $(1998,223)$.

Wave horses are usually masculine and white, but not always. In Virginia Woolf's novel The Waves, becoming-animal waves are described thus: "The waves drummed on the shore, like turbaned warriors, like turbaned men with poisoned assegais who, whirling their arms on high, advance upon the feeding flocks, the white sheep. They fell with a regular thud. They fell with the concussion of horses' hooves on the turf" $(1931,75)$. Robin Hackett argues that this moment in Woolf should be read as an anti-imperialist parody of colonial fantasies about precious white womanhood coming under threat from dark alterity: "the words 'assegais' and 'turbaned' mark these figures as dark-skinned others; the use of warriors as opposed to soldiers primitivizes them" $(2004,69)$. Waves become dark, animal, masculine —other to a domestic, imperiled, sheepish white femininity.

Where might this itinerary from Genesis to the humanimalization of waves arrive? Many places. But let me return to Keller's theological project, tuned to recapturing, remaking, the "face of the deep" - not as essentialist feminine energy, nor as the reanimation of Tiamat, but rather as what Keller calls, with a nod to Donna Haraway, a "trickster matrix" (2003, 193). Committed to a "queer, postcolonial, polymorphous and possibly perverse feminism" (34), Keller writes of a reimagined tehom: "As the wave rolls into realization, it may with an uncomfortable passion fold its relations into the future: the relations, the waves of our possibility, comprise the real potentiality from which we emerge" (236). Keller moves waves into an animal idiom, now calling not upon the equine, but upon the 
cetacean: "We are drops of an oceanic impersonality. We arch like waves, like porpoises" (218). This swerve to porpoises may spiral back to oldschool gender symbolisms, since these creatures are sometimes described as distillations of hydrodynamic femininity (see Bryld 1996). But it may also open up a different becoming-animate materiality. Keller writes, too, that "waves ... [are] membranes of energy from which matter forms and stabilizes" $(2003,232)$. Waves transition between states of energy, operating across matter, gender, and species.

Mel Chen's writings on transgender theory suggest a fresh reading of the prefix trans-: "trans- is not a linear space of mediation between two monolithic, autonomous poles ... I wish to highlight a prefixal trans- no primarily limited to gender" (2012, 136-37; emphasis in original). Thinking of waves' entanglement with gender and animality, we might call wave "tranimals," adapting a term defined by Lindsay Kelley to describe species-, sexuality-, and semiosis-crossing creatures. If attention to the materiality of the nonhuman world-including minerals, toxins, and water-may be key to novel accounts of the animacy of the world, then waves exhibit a kind of tranimacy, becoming tranimate objects. Astrida Neimanis suggests in "Hydrofeminism: Or, On Becoming a Body of Water" that feminist analyses of water politics should step away from essentialist identifications of women with water but not ignore such sex/gender/water eddies as the travel of chemical estrogens through oceans and bodies or, to take an allied example, that "North American breast milk ... likely harbors DDT, PCBs, dioxin, trichloroethylene" $(2012,94){ }^{4}$ The waves of tehom may turn out to be good for thinking with and against gender. In "Has the Queer Ever Been Human?" Dana Luciano and Chen offer the following:

The encounter with the inhuman expands the term queer past its conventional resonance as a container for human sexual nonnormativities, forcing us to ask, once again, what "sex" and "gender" might look like apart from the anthropocentric forms with which we have become perhaps too familiar. (2015, 189; emphasis in original)

Thinking about "sex" and "gender" as they are assigned and undone with respect to nonhumans - as chaotic nature, trickster God, waves, flows of marine toxins-might render the analytic of gender freshly "at sea," as Mother Ocean becomes Other Ocean.

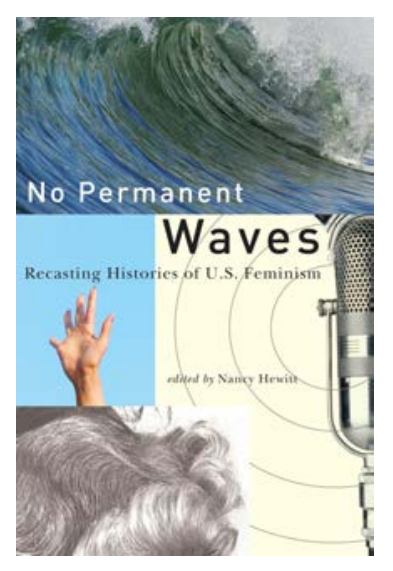

FIG. 3. No Permanent Waves, edited by Nancy Hewitt Book cover, 2010. Reproduced with permission of Rutgers University Press.

\section{Women and/in Waves}

Not only have waves been represented through symbolisms that often gender them as women, but wave imagery has also contoured sociohistorical accounts of the collective lives and politics of women, particularly in the United States. I am inspired to this connection by Nancy Hewitt's 2010 edited volume, No Permanent Waves: Recasting Histories of U.S. Feminism, which unwinds the metaphor of "waves of feminism." This section is an experiment in making explicit the paratactical and discursive connections hinted at by the cover of Hewitt's book, which offers an elaborate visual pun that features ocean waves, a waving hand, radio waves, and a permanent wave hairstyle. What happens when ocean waves as material-formal watery things are left behind, manifesting rather as mobile metaphors for thinking about social agency? Do gendered castings from other contexts follow them, or are these undone and redone?

Let's start with hair. In the wake of World War I, many white American and European middle-class women found their lives transformed as new social possibilities emerged, many a result of the shortage of male labor after the war. On the path to a new independence supported by well-paid office jobs and a sense of the imminent possibility of suffrage, many women signaled their modern status with shorter hairstyles, such as the bob, legible as at once practical and radical. But "simple haircuts for 
women never gained acceptance in the 1920s, at least among the men and women who publicly expressed their opinions" (Søland 2000, 38). Commentators worried that short hair risked blurring the differences between the sexes, masculinizing women, who were disparaged as "boyish." But in the late 1920s, a new technology emerged to offer "feminine and graceful styles with curls and waves" to short hair (quoted in Søland 2000, 38). The "permanent wave," delivering "new curlier versions of bobbed hair ... marked the reestablishment of gender distinctions in fashionable self-presentation" (Søland 2000, 40). Wavy short hair refeminized white women. A 1926 joke in a farmer's magazine quipped, "The ocean must be feminine. Anyway, it early adopted the permanent wave" (Northwest Poultry Journal $1926,34) .5$

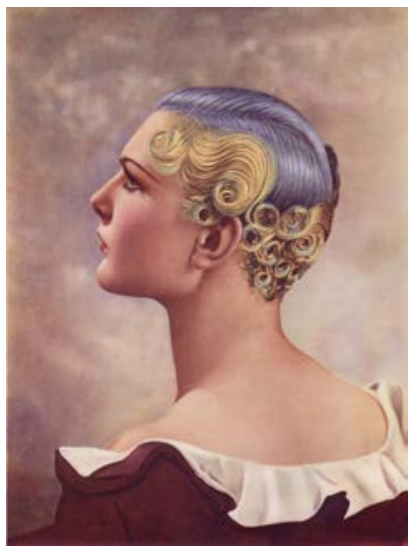

FIG. 4. "First Prize won at the

Hairdressing Fashion Show London, 1935, using an Icall permanent-waving a portion of the hair, on top, that was

colored blue.

While the era around World War I in the United States inaugurated important shifts in the role of women in modern public life, World War II saw a fully state-led rescripting of women's possible identities in line with the figure of the soldier-citizen. During World War II, with many young men away at the front, the military establishment turned to women to fill jobs as engineers, doctors, attorneys, cryptographers, and clerical workers-and also to serve as military officers. In 1942 the U.S. Navy founded Women Accepted for Volunteer Emergency Service (WAVES), placing women into shoreside naval jobs so men in these positions might be sent to sea.

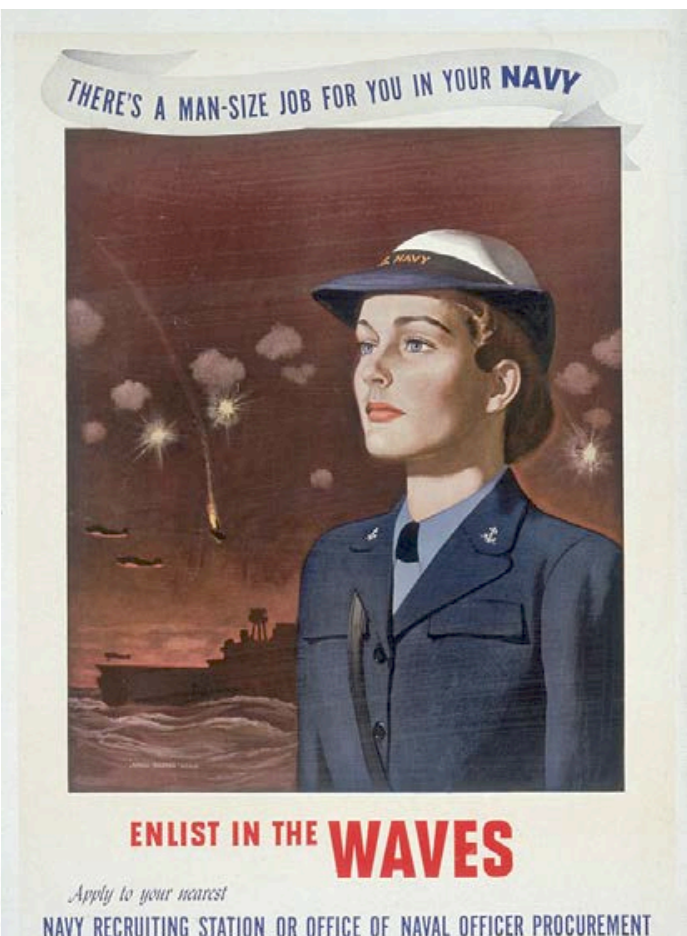

FIG. 5. Recruitment poster for the WAVES, 1940s 
How did the organization come to be called the WAVES? A professor at Barnard, Elisabeth Reynard, who became the unit's assistant director, created the acronym:

I realized that there were two letters which had to be in it: $\mathrm{W}$ for women and $\mathrm{V}$ for volunteer, because the Navy wants to make it clear that this is a voluntary service and not a drafted service. So I played with those two letters and the idea of the sea and finally came up with Women Accepted for Volunteer Emergency Service-WAVES. I figured the word Emergency would comfort the older admirals because it implies that we're only a temporary crisis and won't be around for keeps. (quoted in Hancock 1972, 61)

The association of waves with evanescence and femininity would not have been lost on many publics. But WAVES also summoned the image of a wave of attack, a more battle-ready meaning. WAVES, then, called up symbolism feminine and masculine. Indeed, women in this organization were meant, in the most controlled, heteronormative way, to be both feminine and masculine. They were idealized as "trim girls in the smart navy blue uniform, with its mixture of the romantic and functional" (Ross 1943, 1). The WAVES, numbering around eighty-six thousand at war's end, were overwhelmingly white, meant to stand as a vanguard for traditional American femininity-though also, at moments, for sea changes in gender relations. As Nancy Wilson Ross wrote in her 1943 book on the organization,

No one can write about the WAVES ... without dealing to some extent with their thinking and feeling in this emergency period when the relationship of women to society, and women to men, is so obviously changing.... It would be a bold prophet indeed who attempted to chart these changes, but it would be a blind human being who pretended not to see their shadows cast on the wall. (2)

The WAVES were meant to operate within state institutions and hew to bounded notions of women's status as helpmates to men. But the formation of the organization pointed to transformations in understanding and inhabiting gender, particularly in connection with work and economic independence, transformations that would become the animating concerns of "waves of feminism."

When did the notion of "waves" of feminism take shape? A canonical articulation arrived in a 1968 New York Times Magazine article by Marsha
Weinman Lear, who wrote, "feminism, which one might have supposed as dead as the Polish Question, is again an issue. Proponents call it the Second Feminist Wave, the first having ebbed after the glorious victory of suffrage" (quoted in Henry 2004, 58). ${ }^{7}$ In Not My Mother's Sister: Generational Conflict and Third-Wave Feminism, Astrid Henry notes, "the metaphor of the wave as it was deployed by feminists in the late 1960 s . . . legitimated feminism as a serious and ongoing political struggle with a history while simultaneously granting the second wave a means by which to posit themselves as a vanguard" $(2004,58)$. It may have had earlier precedents, as figure 6 suggests. ${ }^{8}$

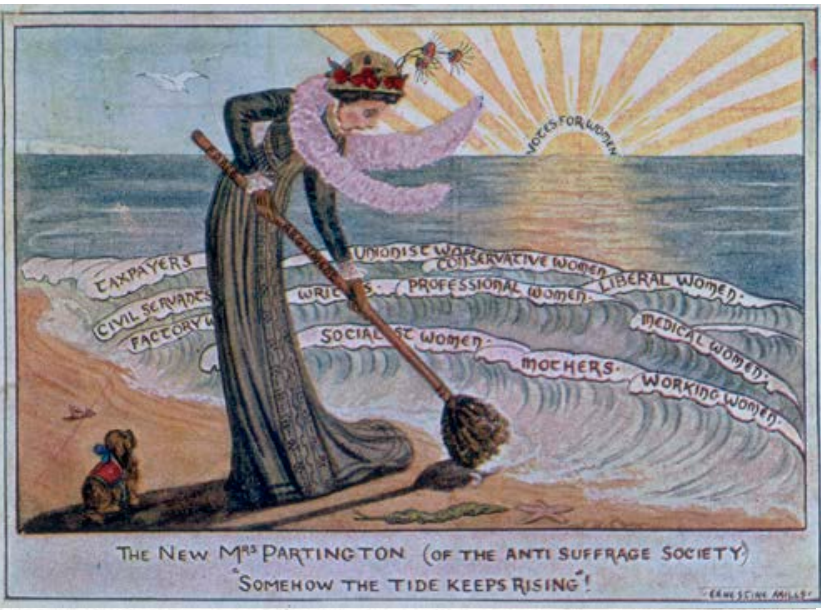

FIG. 6. Ernestine Mills, The New Mrs. Partington, 1905-1914. Reproduced with permission of Getty Images.

By the 1960s, the wave metaphor was seaborne as well as soldierly, echoing and radicalizing the resonances of the U.S. Navy's WAVES - with feminists forming sequenced fronts of change in a longue durée political movement. In the U.S. context where wave imagery gathers force, the first wave came to refer to suffrage movements, the second to 1960s women's liberation, and the third to 1980s and 1990s women-of-color and queer feminism.

But soon after "third-wave feminism" was named, critics pointed to 


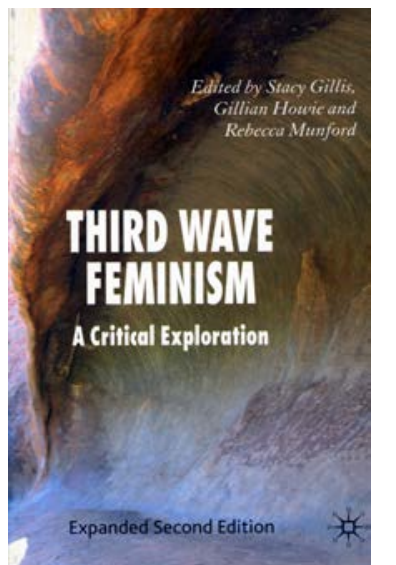

FIG. 7. Third Wave Feminism, edited by Stacy Gillis, Gillian Howie, and Rebecca with permission of Macmillan Scionce an with permissior

limitations of the wave metaphor. Jane Spencer offered that "waves" might usefully render inheritance collective but also warned that positing clean generations erased demographic difference: "essentialism," she wrote, "foams up in all feminist waves" (2007, 300). In 1997, Deborah Siegel coined "feminist oceanography" to describe the possibilities and perils of the "wave" metaphor. The oceanic metaphor under interrogation is not one that has waves as directionless disorder, but one that poses waves as lines of organized energy. In 2004, Lynn Spigel, building on Siegel, wrote:

With both its oceanic and avant-garde connotations, the waves thesis works to place old feminists on the beach—-washed up like fish on the shore. Meanwhile, as in all teleological narratives, the "new" feminist (regardless of her age) is ... fully refreshed by the sea change and outfitted in new feminist swimsuit styles. Having been there and done that, the third-waver rolls past the past, and while she might pay her respect to the waves before her, somehow prior feminisms are represented as something we have "overcome." (2004, 1211-12; see Ahmed 2014 and Slovic 2016)

Ednie Kaeh Garrison took the critique further in 2005, arguing that the wave narrative homogenizes women, linearizes movement, and posits times of lulls, which mismeasures histories of activism: "In the United States the wave metaphor as an analogy for ocean waves constructs certain kinds of historical narratives of women's movements and feminism, narratives which continue to reproduce exclusions and obfuscations" (239; and see Bailey 1997). Ula Taylor (1998) described black feminist waves as differently phased from dominant (white) waves, with different stops and starts of liberation and critique, and Aalya Ahmad (2015) has recently reported that indigenous feminisms, keyed to unceasing resistance to settler colonialism, should be called "no wave feminisms." Agnieszka Graff (2003), looking at Polish feminisms, has suggested that second- and thirdwave characterizations incorrectly mapped the unfolding of socialist and postsocialist time, which shifted from ideologically egalitarian claims about women in public life to newly surfaced inscriptions of gender inequality. Even on their own terms, of course, third-wave feminisms rupture any stability around the category of "women"-or, indeed, "gender." The third wave renders gender a gnarly knot of performances, sexualities, labor hierarchies, racial formations, vectors of desire, and more, with no definitive foundation. Garrison has suggested abandoning the metaphor of the ocean wave:

I want to think about the waves in "third wave feminism" as radio waves. ... [C]onceptualizing multiple waves existing at the same time-sometimes fading and dissolving, other times interrupted or appropriated or colonized, other times overlooked because we can't hear or perceive a signal we haven't got an ear for-disrupts the chronologically and evolutionarily rendered narratives of feminist movements. (2005, 244; see also Hewitt 2010)

Alison Wylie counters that there are still possibilities in the water wave metaphor, and calls for repurposing these, writing that

waves do not so much overtake and succeed/supersede one another as rise and fall again and again in the same place, transmitting energy in complicated ways. ... [W]aves propagate and interact even in the simplest of circumstances.... [W] aves are generated in many different ways: by river or tidal currents, by snags and obstructions under water, by wind and traffic on the surface, and, on rare and catastrophic occasion, by grinding shifts in tectonic plates. $(2006,173)$

What is notable about Garrison and Wylie's interventions is their dive into scientific imagery; they are recuperative moves not unlike Keller's call upon the idioms of physics to take waves as trickster mixes of matter 
and form. ${ }^{9}$ Rodgers, drawing in part on Woolf's The Waves (see also Beer 2014), has also offered a recuperation of "waves" as "the contingencies of mutual contact rather than a disturbance or medium of conquest" (2016, 208). This makes waves something like a matrix of succession and disruption that is neither linearly repetitive nor chaotic. Such rereadings, drawing upon scientific language (compare to Roosth and Schrader 2012), might, to borrow a theoretical intervention from Kath Weston, "unsex" waves. Weston writes that to unsex is to create a space in which exists "a temporary suspension of gender" $(2002,29)$. "Unsexed," she writes, "unsettles the presumption that discussions of gender must ultimately refer back to genders" (40). This can be the case not only with gender as it pertains to humans, but also as it is summoned to describe nonhumans (such as waves) as well as suprahuman collectives (such as waves of social change).

\section{Conclusion}

Canonical analytics of gender-as both "a concept developed to contest the naturalization of sexual difference" (Haraway 1991, 131) and as "a system of social, symbolic, and psychic relations” (143, paraphrasing Evelyn Fox Keller) - have been crucial for decoding the gendering not only of human bodies, but also of animals (see Schiebinger 1993 on "why mammals are called mammals"), plants (see Hustak and Myers's 2012 critique of "sexual deception" in orchids), commodities, gods, materials, concepts (see Lutz 1995 on "the gender of theory"), and of places, spaces, and substances, including the sea. Such analytics, particularly combined with critical race theory and queer theory, have unwound the doubling oppositions that have aligned gender with male and/or female. They have also tangled notions of a "continuum" between two sexes, deforming linear account of third, fourth, and fifth genders, intersex, and various interstitial transgenders (Weston 2002). Such denaturalizing moves have also fed a more "diffractive" model of difference (see Haraway 1997) of the sort enunciated by Karen Barad, who offers that "diffraction does not fix what is the object and what is the subject in advance" $(2008,30)$. Drawing on wave imagery, Barad writes, "Diffraction can occur with any kind of wave: fo example, water waves, sound waves, and light waves.... The ocean waves are thus diffracted as they pass through the barrier; the barrier serves as a diffraction apparatus for ocean waves" (74). As difference engines, diffracted waves may or may not produce those forms we have come to know as "gender." 10

At the same time, in the second decade of the twenty-first century, when social scientific and humanistic theory draws toward the posthuman and inhuman, analytics of gender, race, and class do not become obsolete. The turn to materiality, to empiricity, and in some cases to scientific language, does not banish older genderings and racializations of the sea. Still, such analytics as gender, sexuality, and/or queerness are no longer fully attached, if ever they were, only to "the human" (Luciano and Chen 2015), a fact that places them freshly at sea, wavering, and, perhaps, available to new kinds of gender trouble and turbulence.

\section{Acknowledgments}

I thank Elizabeth DeLoughrey, Eva Hayward, Melody Jue, Jia-Hui Lee, Heather Paxson, and Sophia Roosth for comments. I also thank editors of this issue of WSQ and the two reviewers.

Stefan Helmreich is professor of anthropology at MIT. He is the author of Alien Ocean Anthropological Voyages in Microbial Seas and Sounding the Limits of Life: Essays in the Anthropology of Biology and Beyond. Readers may contact Helmreich at sgh2@ mit.edu.

\section{Notes}

1. No surprise. In Shipwreck Modernity, Steve Mentz writes that, "history as we encounter it in texts and representations is shot through with multiple temporalities ... a productive and disorienting swirl" $(2015, \mathrm{x})$.

2. A more thorough treatment would examine mathematical descriptions of waves (see Helmreich 2015). It would also investigate rhetoric in surfing, which has also seen waves gendered-often, by straight male surfers, as lovers/mothers

3. In Octavio Paz's 1949 short story, "My Life with the Wave," a male protagonist succumbs to a wave as a tempestuous seductress, but then domesticates and dissolves "her," in a mermasculine heterosexual conquest.

What to make of nineteenth-century paintings of nude white women with waves? In these images waves are sexualized, though ambiguously (see Ortberg 2016). Are they male lovers? Euro-Romantic Sapphic adjuncts to their companion women?

4. Eva Hayward, writing of "transxenoestrogenesis," observes that "polar bears, 
alligators, frogs, mollusks, fish, and birds are numbered among more than two hundred animal species around the world that are indeed already responding physically to hormone-altering xenoestrogenic pollutants in their environments" $(2014,257)$. Hayward suggests that such putatively "natural" indicators of "sex" as hormones have been redone by oceanic flows of pollution (see also Ah-King and Hayward 2014). J. K. Gibson-Graham (2011) pointing to environmental justice movements, writes of how water distribution channels and complicates shoreside hierarchies of gender, race, class, and sexuality.

5. African American women employed the same heating technology behind permanent wave machines to straighten their hair. For white women,

in a racially segregated milieu, a permanent wave was perhaps the safest way for white women to transgress forbidden racial barriers. If the symbolic importance of hair texture-its straightness or "kinkiness" - is indeed crucial in constructing notions of racial categorization, then white women's desire to "friz" their hair must be understood in terms of their ambivalence surrounding racial identities... perming one's hair, like other forms of racial cross-dressing, allowed white women to flaunt a sense of recklessness yet ultimately retain their own notions of respectability. (Willet 2000, 49-50)

6. In 1999 Dutch physician Rebecca Gomperts founded Women on Waves (WoW) as a service providing non-surgical abortion on a ship, that, flying a Dutch flag, can operate in international waters, serving as an island of Dutch reproductive law (Skinner 2007)

7. Hewitt points to a use in 1884, by Frances Power Cobbe, who suggested that social movements "resemble the tides of the Ocean" (xiii), and that women's movements in particular have "rolled in separate waves" (xiv).

8. See Delap 2011 on maritime imagery in UK suffrage movements.

9. Writing of a possible "fourth-wave" feminism, Evans and Chamberlain employ a hydromolecular simile to suggest that "the wave could be most useful when considered as a surface cohesion" $(2015,401)$.

10. Or, for that matter, "race," which Weheliye (2014) has theorized as a viscous form, emerging in assemblage with corporeal, social, and economic forces.

\section{Works Cited}

Ah-King, Malin, and Eva Hayward. 2014. "Toxic Sexes: Perverting Pollution and Queering Hormone Disruption.” O-Zone: A Journal of Object-Oriented Studies 1: 1-12.

Ahmad, Aalya. 2015. "Feminism Beyond the Waves." Briarpatch, July/August: https://briarpatchmagazine.com/articles/view/feminism-beyond-thewaves.

Ahmed, Sara. 2014. "Dated Feminists." Feminist Killjoys (blog). https:// feministkilljoys.com/2014/04/08/dated-feminists/.

Alaimo, Stacy. 2016. Exposed: Environmental Politics and Pleasures in Posthuman Times. Minneapolis: University of Minnesota Press.

Andrews, Tamra. 1998. A Dictionary of Nature Myths: Legends of the Earth, Sea, and $S k y$. Oxford: Oxford University Press.

Bachelard, Gaston. 1983. Water and Dreams: An Essay on the Imagination of Matter. Translated by Edith Farrell. Dallas: The Dallas Institute of Humanities and Culture.

Bailey, Cathryn. 1997. "Making Waves and Drawing Lines: The Politics of Defining the Vicissitudes of Feminism." Hypatia 12 (3): 17-28.

Barad, Karen. 2008. Meeting the Universe Halfway: Quantum Physics and the Entanglement of Matter and Meaning. Durham, NC: Duke University Press. Beer, Gillian. 2014. “On Virginia Woolf's The Waves." Daedalus 143 (1): 54-63. Bennett, Jane. 2010. Vibrant Matter: A Political Ecology of Things. Durham, NC: Duke University Press.

Braidotti, Rosi. 2013. The Posthuman. Cambridge: Polity Press.

Bryld, Mette. 1996. "Dialogues with Dolphins and Other Extraterrestrials: Displacements in Gendered Space." In Between Monsters, Goddesses, and Cyborgs: Feminist Confrontations with Science, Medicine, and Cyberspace, edited by Nina Lykke and Rosi Briadotti, 47-71. London: Zed Books.

Butler, Judith. 1993. Bodies that Matter: On the Discursive Limits of "Sex." New York: Routledge.

. 2004. Undoing Gender. New York: Routledge.

Chen, Mel Y. 2012. Animacies: Biopolitics, Racial Mattering, and Queer Affect. Durham, NC: Duke University Press.

Cobbe, Frances Power. 1884. "Introduction." In The Woman Question in Europe: A Series of Original Essays, edited by Theodore Stanton, xiii-xviii. New York: G. P. Putnam's Sons.

Cohen, Jeffery Jerome. 2015. Stone: An Ecology of the Inhuman. Minneapolis: University of Minnesota Press.

Coole, Diana, and Samantha Frost, eds. 2010. New Materialisms: Ontology, Agency, and Politics. Durham, NC: Duke University Press.

Corbin, Alain. 1995. The Lure of the Sea: The Discovery of the Seaside 1750-1840. Translated by Jocelyn Phelps. Harmondsworth, UK: Penguin.

Crutzen, Paul J., and Eugene F. Stoermer. 2000. “The Anthropocene.” Global Change Newsletter 41: 17-18.

Delap, Lucy. 2011. “The Woman's Dreadnought: Maritime Symbolism in 
Edwardian Gender Politics." In The Dreadnought and the Edwardian Age, edited by Andrew Lambert, Robert Blythe, and Jan Rüger, 95-108. Surrey, UK: Ashgate.

Ehrenreich, Barbara. 1987. "Foreword." In Male Fantasies, Vol. 1: Women, Floods, Bodies, History, by Klaus Theweleit, ix-xvii. Minneapolis: University of Minnesota Press.

Evans, Elizabeth, and Prudence Chamberlain. 2015. "Critical Waves: Exploring Feminist Identity, Discourse and Praxis in Western Feminism." Social Movement Studies 14 (4): 396-409.

Garrison, Ednie Kaeh. 2005. "Are We on a Wavelength Yet? On Feminis Oceanography, Radios, and Third Wave Feminism." In Different

Wavelengths: Studies of the Contemporary Women's Movement, edited by Jo Reger, 237-56. New York: Routledge.

Gibson-Graham, J. K. 2011. "A Feminist Project of Belonging for the Anthropocene." Gender, Place \& Culture 18 (1): 1-21

Graff, Agnieszka 2003. "Lost between the Waves? The Paradoxes of Feminist Chronology and Activism in Contemporary Poland." Journal of International Women's Studies 4 (2): 100-16.

Grosz, Elizabeth. 1994. Volatile Bodies: Toward a Corporeal Feminism. Bloomington: Indiana University Press.

Grusin, Richard. 2015. The Nonhuman Turn. Minneapolis: University of Minnesota Press.

Hackett, Robin. 2004. Sapphic Primitivism: Productions of Race, Class, and Sexuality in Key Works of Modern Fiction. New Brunswick, NJ: Rutgers University Press.

Hancock, Joy Bright. 1972. Lady in the Navy: A Personal Reminiscence. Annapolis, MD: Naval Institute Press.

Haraway, Donna J. 1991. “'Gender' for a Marxist Dictionary.” In Simians, Cyborgs, and Women: The Reinvention of Nature, 127-48. New York: Routledge. -1997.Modest_Witness@Second_Millennium.FemaleMan@ Meets OncoMouse $e^{\text {tux }}$ :Feminism and Technoscience. New York: Routledge.

Hayward, Eva. 2014. “Transxenoestrogenesis.” TSQ: Transgender Studies Quarterly 1 (1): 255-58.

. 2015. "Tranimacies: An Interview with Mel Y. Chen." TSQ: Transgender Studies Quarterly 2 (2): 317-23.

Helmreich, Stefan. 2015. "Old Waves, New Waves: Changing Objects in Physical Oceanography." In Fluid Frontiers: New Currents in Marine and Maritime Environmental History, edited by John Gillis and Franziska Torma, 76-88. Cambridge: White Horse Press.

Henry, Astrid. 2004. Not My Mother's Sister: Generational Conflict and Third-Wave
Feminism. Bloomington: Indiana University Press.

Hewitt, Nancy, ed. 2010. No Permanent Waves: Recasting Histories of U.S. Feminism. New Brunswick, NJ: Rutgers University Press.

Hustak, Carla, and Natasha Myers. 2012. "Involutionary Momentum: Affective Ecologies and the Sciences of Plant/Insect Encounters." differences 23 (5): 74-118.

Irigaray, Luce. 1985. “The 'Mechanics' of Fluids." In This Sex Which Is Not One, translated from the French by Catherine Porter with Carolyn Burke. Ithaca, NY: Cornell University Press.

Keller, Catherine. 2003. The Face of the Deep: A Theology of Becoming. London: Routledge.

Kelley, Lindsay. 2014. “Tranimals.” TSQ: Transgender Studies Quarterly 1 (1): 226-28.

Kirksey, Eben, ed. 2014. The Multispecies Salon. Durham, NC: Duke University Press.

Lindow, John. 2001. Norse Mythology: A Guide to Gods, Heroes, Rituals, and Beliefs. Oxford: Oxford University Press.

Longfellow, Henry Wadsworth. 1885. The Poetical Works of Henry Wadsworth Longfellow. Boston: Houghton, Mifflin, and Company.

Luciano, Dana, and Mel Y. Chen. 2015 "Has the Queer Ever Been Human?" GLQ: A Journal of Lesbian and Gay Studies 21: 2-3.

Lutz, Catherine. 1995. "The Gender of Theory." In Women Writing Culture, edited by Ruth Behar and Deborah A. Gordon, 249-66. Berkeley: University of California Press.

Mentz, Steve. 2015. Shipwreck Modernity: Ecologies of Globalization, 1550-1719. Minneapolis: University of Minnesota Press.

Morton, Timothy. 2013. Hyperobjects: Philosophy and Ecology after the End of the World. Minneapolis: University of Minnesota Press.

Neimanis, Astrida. 2012. "Hydrofeminism: Or, On Becoming a Body of Water. In Undutiful Daughters: New Directions in Feminist Thought and Practice, edited by Henriette Chrysanthi Nigianni Gunkel and Fanny Söderbäck, 85-99. New York: Palgrave MacMillan.

Nietzsche, Friedrich. (1882) 1974. The Gay Science. Translated by Walter Kaufmann. New York: Vintage Books.

Northwest Poultry Journal. 1926. Statement Publishing Company.

Ortberg, Mallory. 2016. "Women Inexplicably Aroused by Wave in Art." Toast, January 25. http://the-toast.net/2016/01/25/ women-inexplicably-aroused-by-waves-in-art/.

Paz, Octavio. 1949. “Mi Vida con la Ola." In Arenas Movedizas. Mexico City Alianza Cien. 
Quinn, Judy. 2014. “Mythologizing the Sea: The Nordic Sea-Diety Rán.” In Nordic Mythologies: Interpretations, Intersections, and Institutions, edited by Timothy R. Tangherlini, 71-99. Berkeley, CA: North Pinehurst Press.

Raban, Jonathan. 2010. "The Waves." In Driving Home: An American Journey, 159-64. New York: Pantheon Books.

Rodgers, Tara. 2016. "Toward a Feminist Epistemology of Sound: Refiguring Waves in Audio-Technological Discourse." In Engaging the World: Thinking after Irigaray, edited by Mary Rawlinson, 195-214. Albany, NY: SUNY Press.

Roosth, Sophia, and Astrid Schrader. 2012. "Feminist Theory Out of Science." differences 23 (5): 1-8.

Ross, Nancy Wilson. 1943. The WAVES: The Story of the Girls in Blue. New York: Henry Holt and Co.

Schiebinger, Londa. 1993. "Why Mammals Are Called Mammals: Gender Politics in Eighteenth-Century Natural History." The American Historical Review 98 (2): 382-411.

Siegel, Deborah L. 1997. "The Legacy of the Personal: Generating Theory in Feminism's Third Wave." Hypatia 12 (3): 46-75.

Skinner, Althea. 2007. "Women on Waves: Navigating National and International Laws and Values," Humanity in Action. http://www. humanityinaction.org/knowledgebase/152-women-on-waves-navigatingnational-and-international-laws-and-values.

Slovic, Scott. 2016. "Seasick among the Waves of Ecocriticism: An Inquiry into Alternative Historiographic Metaphors." In Environmental Humanities: Voices from the Anthropocene, edited by Serpil Oppermann and Serenella Iovino, 99-111. Lanham, MD: Rowman and Littlefield.

Søland, Birgitte. 2000. Becoming Modern: Young Women and the Reconstruction of Womanhood in the 1920s. Princeton, NJ: Princeton University Press.

Spencer, Jane. 2007. “Afterword: Feminist Waves." In Third Wave Feminism: A Critical Exploration, edited by Stacy Gillis, Gillian Howie, and Rebecca Munford, 298- 303. 2nd edition. New York: Palgrave Macmillan.

Spigel, Lynn. 2004. “Theorizing the Bachelorette: 'Waves' of Feminist Media Studies." Signs 30 (1): 1209-21.

Spillers, Hortense J. 1987. “Mama’s Baby, Papa’s Maybe: An American Grammar Book.” Diacritics 17 (2): 64-81.

Steinberg, Philip, and Kimberley Peters. 2015. "Wet Ontologies, Fluid Spaces Giving Depth to Volume through Oceanic Thinking." Environment and Planning D: Society and Space 33: 247-64.

Sturluson, Snorri. ( 1200) 1916. The Prose Edda. Translated by Arthur Gilchrist Brodeur. New York: The American-Scandinavian Foundation
Taylor, Ula Y. 1998. "Making Waves: The Theory and Practice Of Black Feminism." The Black Scholar 28 (2): 18-28.

Theweleit, Klaus. 1987. Male Fantasies, Vol. 1: Women, Floods, Bodies, History. Minneapolis: University of Minnesota Press.

Weheliye, Alexander. 2014. Habeas Viscus: Racializing Assemblages, Biopolitics, and Black Feminist Theories of the Human. Durham, NC: Duke University Press.

Weston, Kath. 2002. Gender in Real Time: Power and Transience in a Visual Age. New York: Routledge.

Willet, Julie A. 2000. Permanent Waves: The Making of the American Beauty Shop. New York: NYU Press.

Wolfe, Cary. 2009. What Is Posthumanism? Minneapolis: University of Minnesota Press.

Wolfenstein, Eugene Victor. 2000. Inside/Outside Nietzsche: Psychoanalytic Explorations. Ithaca, NY: Cornell University Press.

Woolf, Virginia. (1931) 1959. The Waves. San Diego: Harcourt. Reprint, New York: Harcourt Brace \& Company.

Wylie, Alison. 2006. "Afterword: On Waves." In Feminist Anthropology: Past, Present, and Future, edited by Pamela L. Geller and Miranda K. Stockett, 167-76. Philadelphia: University of Pennsylvania Press. 